\title{
A Comparative Study of Irradiation Systems for Photoinactivation of Microorganisms
}

\author{
Lucas F. de Paula, ${ }^{*, a}$ Renata O. Santos, ${ }^{a}$ Henrique D. Menezes, ${ }^{a}$ Jonas R. de Britto, ${ }^{b}$ \\ João B. Vieira Jr., ${ }^{b}$ Paulo P. Gontijo Filho ${ }^{c}$ and Carlos A. de Oliveira ${ }^{a}$ \\ ${ }^{a}$ Instituto de Química, ${ }^{b}$ Faculdade de Engenharia Elétrica and ${ }^{c}$ Núcleo de Imunologia, Microbiologia e \\ Parasitologia, Universidade Federal de Uberlândia, 38408-100 Uberlândia-MG, Brazil
}

Estudou-se a construção de sistemas de LED aplicados a processos de fotosensitização. Visando à obtenção de dispositivos mais eficientes avaliou-se a aplicação de LED de alta potência (HPLED), que apresenta maior fluxo fotônico, tendendo a excitar uma maior fração de moléculas. Foram descritos detalhes de construção de 3 diferentes sistemas de irradiação completamente distintos (lâmpada halógena filtrada, LED convencional, HPLED), utilizando azul de metileno como fotosensitizador. A comparação entre a eficiência de cada equipamento foi realizada através da cinética de fotooxidação de 1,3-Diphenylisobenzofuran e inativação de Staphylococcus aureus. A emissão de luz de cada equipamento, sobreposta à absorção do fotosensitizador, também se mostrou um importante parâmetro na estimativa da eficiência dos equipamentos. Foi observada uma inibição bacteriana superior a $99 \%$ para concentrações de $5 \times 10^{-6} \mathrm{~mol} \mathrm{dm}^{-3}$ de fotosensitizador, no sistema que emprega HPLED. Os equipamentos baseados em LED, apresentaram resultados satisfatórios além de baixo custo e simples montagem.

The construction of LED systems applied to photosensitization processes was studied. Aiming to obtain more efficient devices it was evaluated the use of high intensity LED (HPLED), that present greater photonic flux, tending to excite a greater fraction of molecules. Construction details for 3 different irradiation systems were described (filtered halogen bulbs, conventional LED, HPLED), using methylene blue as a photosensitizer. A comparison between the efficiency of the equipments was carried out through the kinetics of photooxidation of 1,3-Diphenylisobenzofuran and Staphylococcus aureus photoinactivation. The overlap between the light emited from each equipment and the photosensitizer absorption, was also an important parameter in estimating the efficiency of the equipment. Bacterial inhibition higher than $99 \%$ for concentrations of $5 \times 10^{-6} \mathrm{~mol} \mathrm{dm}^{-3}$ of the photosensitizer was observed, in the system that uses HPLED. The equipments based on LED showed satisfactory results, besides their low cost and simple to assembling.

Keywords: high power LED, Staphylococcus aureus, methylene blue, irradiation systems

\section{Introduction}

Photodynamic Inactivation (PDI) ${ }^{1}$ or Photodynamic Antimicrobial Chemotherapy (PACT) $)^{2}$ is the name of a process, derived from Photodynamic Therapy, that causes the death of microorganisms under the action of visible light and a specific drug, also called photosensitizer. ${ }^{3}$ The electronic excitation of the photosensitizer in the presence of oxygen implies in the generation of a large number of reactive oxygen species (ROS), as for example, singlet oxygen, ${ }^{4,5}$ in a process known as photosensitization.

Since 1976, the oxidative action of singlet oxygen and other ROS on tumor cells has been reported in the

*e-mail: msc_lucasferreira@yahoo.com.br medical and scientific communities. ${ }^{5,6}$ Around the world, several research results have been published on the use of photosensitization to fight diseases caused by fungi, viruses, bacteria and yeasts. ${ }^{3,5,7-11}$

Among the photosensitizers cited in the literature, ${ }^{12-16}$ methylene blue (MB), a phenothiazinic dye, has some convenient characteristics: it presents good photodynamic activity compared to different substrates, ${ }^{17-19}$ is nontoxic and relatively inert on living organisms. ${ }^{20}$ It is also known for its anti-septic action ${ }^{21}$ and has been administrated intravenously in some clinical cases (e. g., the treatment of methemoglobinemia). ${ }^{22,23}$

The light used in the photoinactivation systems needs to comply with certain requirements: emission filtered with low interference (i.e., relative monochromaticity); 
appreciable area of incidence; adjusted spectral emission (near the drug absorption peak); low heating; appreciable intensity. ${ }^{24}$ Therefore, light emitting diodes (LED) present some very desirable characteristics such as physical resistance (they do not have bulbs, they do not break and they are quite robust); extended duration (useful lifetime nearly $100,000 \mathrm{~h}$ ); spectral emission near to monochromatic systems; availability in several colors; low heat emission; ${ }^{25,26}$ aside from having lower cost per unit of power when compared to laser diode systems. ${ }^{27}$

In recent years, several publications point out to the use of LED as a source of irradiation to satisfactorily promote the excitement of photosensitizers. ${ }^{28-31}$ However, the present work aims at comparing and demonstrating advantages in the use of high intensity LED, in detriment to conventional LED, aside from providing guidelines for constructing an irradiation equipment based on LED arrays. Conventional colored 3 and $5 \mathrm{~mm}$ LED, widely found on the market, normally operate under a forward current of $20 \mathrm{~mA}$, and have decreased rates of luminous emission (normally not exceeding 5,000 mcd). ${ }^{32}$ With the intention of making up for this disadvantage, two alternatives can be used: $(i)$ the confection of LED arrays that not only increase the incidence area, but also potentialize the intensity of emitted radiation; (ii) application of high power LED (AMS-II). They are more powerful than the previous ones, and have high rates of luminous conversion - about $33 \mathrm{~lm} \mathrm{~W}^{-1}$ for the red AMS-II. ${ }^{26}$ This indicates that they use less energy to emit the same luminous amount, aside from maintaining good characteristics as durability and emission close to monochromatic.

The photodynamic action of MB was explored in the sense of correlating the efficiency of three different irradiation sources: (i) an equipment issuing polychromatic filtered radiation coming from a halogen lamp called PHLS (Polychromatic Halogen Lamp System); (ii) matrix of 600 high brightness conventional
LED, called LED600; (iii) irradiation equipment emitted by high intensity LED, assembled for a better performance in the methylene blue sensitization and the analogous ones, denominated AMS-II.

The effective irradiance and the overlap integral with the absorption band of MB of each equipment were analyzed. Their efficiencies in ROS generation were analyzed by means of a kinetic study of discoloration of 1,3-Diphenylisobenzofuran (DPBF), a colorful molecule that quickly suffers oxidation in the presence of singlet oxygen, forming $o$-dibenzoylbenzene (DBB).$^{33}$ As a microorganism model, for implementing and measuring photoinactivation efficiency, Staphylococcus aureus, which is a pathogenic gram-positive bacteria widely studied and responsible for several reports of hospital infection ${ }^{34}$ was used.

\section{Experimental}

\section{PHLS setup}

A halogen lamp used in overhead projectors (OSRAM, model ENH, 250W) was fitted to a metallic box. A $100 \%$ reading magnifying lens was fixed at a distance of $7 \mathrm{~cm}$ from the light bulb. For refrigeration, a cooler was inserted in the metallic box, and was fitted to a glass cube near the irradiation point of the sample being rectangular in shape for circulating water on the inside.

The light given off by the light bulb was then filtered to eliminate unnecessary wavelengths using an optic filter. The filter was obtained commercially and is made of pigmented polyester. The filter was fitted on the top of the glass box. A schematic view of this setup is shown in Figure 1A.

\section{LED600 equipment}

Under a typical circuit board, the matrix of 600 high brightness red LED (ZX, $8000 \mathrm{mcd}$ ) was made. This

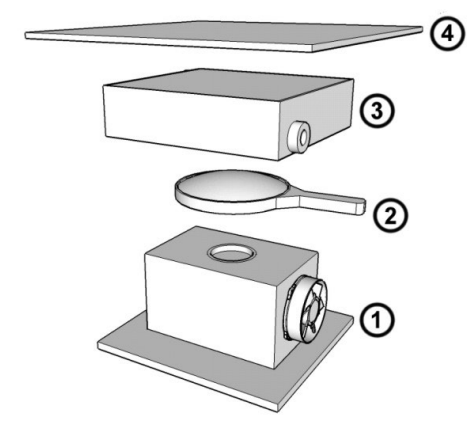

A

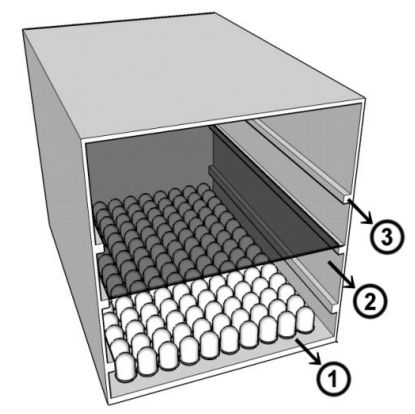

B

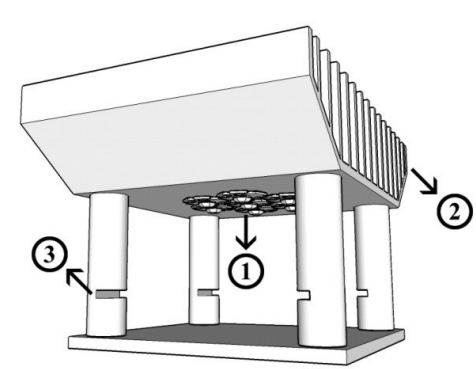

C

Figure 1. A) Equipment PHLS (1) Metal carcasses with the coupled lamp and cooler, (2) Magnifying glass, (3) Glass box, (4) Optical filter; B) LED600 equipment (1) Arrangement of high brightness LED, (2) Translucent mobile support for sample setting, (3) Height groove, for support setting; C) AMS-II equipment (1) Arrangement of high power LED, (2) Heat processor dissipater, (3) Groove for support setting for the insertion of the sample. 
array was organized in 150 clusters connected in parallel, each cluster having 4 LED in series. This entire array was connected and fed by a DC power supply, providing 2.42 A current.

This circuit board was fixed to a rectangular metallic box. It was welded onto the metallic structures, on the inside there are some structures that allow for sample fixation. The described structure is shown in the Figure 1B.

\section{AMS-II equipment}

Seven High Intensity LEDs were assembled in a serial array (Figure 1C) (Edison, model IR Edixeon). The LED was driven by a Buck $\mathrm{CC} / \mathrm{CC}$ converter that delivers an output voltage of 22VDC and a constant output current of $350 \mathrm{~mA}$, from a universal input voltage (100-240 $\left.\mathrm{V}_{\mathrm{AC}}\right)$. Therefore the total power given off by the LED is about $7.5 \mathrm{~W}$.

\section{Acquisition of irradiance spectra and measurements}

The profile of the emitted radiation of the abovementioned light sources was obtained with the aid of a setup based on an Ocean Optics, model SD2000 fiber optics spectrometer with an integrated time of $35 \mathrm{~ms}$.

The optical power $(\mathrm{P})$ was obtained with the aid of a power meter Ophir, model Orion, with a photodiode sensor model PD-300, spectral range of 350-1100 nm.

Aiming at the comparison between the proposed systems, an integral of overlapping was estimated (R) between the absorption of the methylene blue $\left(\mathrm{ABS}_{\mathrm{PS}}\right)$ and the emission of the irradiation equipment $\left(\mathrm{E}_{\mathrm{EQUIP}}\right)$ (equation 1), according to the method proposed by Bonacin et al. ${ }^{31}$

$\mathrm{R}=\int \mathrm{ABS}_{\mathrm{PS}} \mathrm{E}_{\mathrm{EQUIP}} \mathrm{d} \lambda$

Because the irradiation intensity does not vary with time, it is possible to estimate the relative fraction of photosensitizer excitement $(\mathrm{R})$ which is an important parameter for comparing the efficiency between the equipments described.

Due to the fact that the concentration of dye used is the same, the greater or lesser values of $\mathrm{R}$ are associated only to the coupled emission with the absorption of the dye, and represented a magnitude of excitement of the dye molecules.

\section{Methylene blue}

Methylene blue solutions (Sigma) in the concentrations $5 \times 10^{-5}, 5 \times 10^{-6}$ and $5 \times 10^{-7} \mathrm{~mol} \mathrm{dm}^{-3}$, have been prepared, in a laminar flow hood, through the dissolution of the dye in sterile physiological serum (sodium chloride saline solution $0.9 \mathrm{wt} \%$ sterilized by autoclave) and deposited in Eppendorf tubes before use.

The methylene blue absorption spectrum in physiological solution, in a solution $10^{-6} \mathrm{~mol} \mathrm{dm}^{-3}$, was measured using a Shimadzu UV-2501 spectrophotometer.

\section{DPBF oxidation}

Stock solutions $\left(10^{-4} \mathrm{~mol} \mathrm{dm}^{-3}\right)$ of DPBF (Sigma) were diluted in absolute methanol, resulting in a final concentration of $10^{-5} \mathrm{~mol} \mathrm{dm}^{-3}$ and $10^{-6} \mathrm{~mol} \mathrm{dm}^{-3}$ of methylene blue. All these solutions were prepared at the moment of use, and protected from light before the experiments were carried out.

The solutions were irradiated using an open quartz cuvette (Hellma 110-QS) with a $1 \mathrm{~cm}$ optical pathway, being stirred constantly, at intervals of $5 \mathrm{sec}$ of irradiation, and absorption was read at $408 \mathrm{~nm}$, with the aid of a spectrophotometer.

Sodium azide (Aldrich, 99.99\%) was used as a singlet oxygen quencher in some experiments.

A comparative measure at the number of photons absorbed by the concentration of oxidable substract was used as to help estimating the efficiency of each equipment. Consequently, the equipment that promotes a greater substract degradation emitting a smaller quantity of photons tends to be more efficient.

\section{Bacterial suspension}

Determined S. aureus strain (ATCC 25923), was kindly provided by the Laboratório de Microbiologia, Universidade Federal de Uberlândia. This strain was transferred to a nutritional medium prepared with the following composition: $1.25 \%$ meat extract 'lab lemco' (Oxoid), $0.50 \%$ tryptone (Oxoid), $1.00 \%$ peptone (Biobrás), $0.50 \%$ sodium chloride (Vetec, $99 \%$ ), $0.25 \%$ sodium phosphate dibasic heptahydrated (Cinética química, 99\%), $2.00 \%$ D-glucose (Synth, 99.9\%).

A secondary culture was carried out in agar CistineLactose-Electrolyte-Deficient - CLED (Oxoid), used for the growth and isolation of CFU's.

From this culture a bacterial suspension was prepared in sterile physiological serum/saline. In the bacteriological experiment a concentration of 0.1 in the McFarland scale was used. This stock suspension was diluted in a 1:10 proportion, which corresponds to a cell density of approximately $3 \times 10^{6}$ colony forming units (CFU) $\mathrm{mL}^{-1}$. 


\section{Incubation and irradiation}

$500 \mu \mathrm{L}$ of bacterial suspension and $500 \mu \mathrm{L}$ of methylene blue solution were incubated, in the dark, for $30 \mathrm{~min}$. This experiment was repeated for each concentration of methylene blue prepared. All experiments were carried out in triplicate.

After the incubation period, the samples were irradiated, for $20 \mathrm{~min}$, without agitation, and subsequently $100 \mu \mathrm{L}$ of the suspension were transferred to Petri dishes containing the casting growth medium and kept in the bacteriological stove at $35^{\circ} \mathrm{C}$. This medium was prepared by adding $2 \%$ of agar to the nutritional broth formula. After $24 \mathrm{~h}$ of incubation, colony counting was carried out using a colony counter PHOENIX (CP 602).

\section{Results and Discussion}

\section{Development of the equipment}

The LED of the AMS-II equipment was arrayed in series, because in this way the equipment would be better adjusted to the photochemical processes (satisfactory intensity, homogeneous, fixed and steady irradiance). Arraying series and regulating the current (and not the tension) through of the LED, is preferred for these applications, provided: $(i)$ The curve between the current and LED voltage is very abrupt: ${ }^{26}$ Small changes in the voltage are expressed in great variations of current. Once the luminous intensity of the LED alternates more linearly with the current, subtle alterations in the voltage would imply in drastic changes in the intensity. While simple systems of current control, tend to ensure greater confidence in the luminous intensity oscillation. (ii) In regard to the voltage and the natural negative temperature coefficient of LED, arrays connected in parallel cannot guarantee that the current (and thus the brightness) entering each LED is necessarily equal. When two diodes are connected in parallel and one of them heats a little more than the other, this diode tends to drain more current, becoming hotter and in this way contributes gradually to a cascade effect that normally culminates in overheating.

LED600, unfortunately, for practical reasons, cannot be arrayed in series, since the tension in components in series is cumulative, and, therefore the equipment would tend to consume a tension of nearly 1320 Volts (assuming $2.2 \mathrm{~V}$ as the approach tension of each diode), making the project impracticable. In practice it was observed that for the array in LED600 having been carried in a rather compact form, the homogeneity is not so compromised, and the current limitation, for the use of an appropriate source, reduces part of the problems related to the arrays in parallel. Moreover, LED600 has innumerable components. If it was mounted in series and one of the diodes were damaged, opening the circuit, all illumination of the set would be compromised. For these and other reasons the AMS-II equipment was theoretically considered as LED600 improvement, developed to work in series, with a fixed current.

The production cost of the PHLS is at least twice less costly than the other devices developed. This equipment is also much more accessible than analogous commercial equipment. The lens used greatly reduce the area of homogeneous radiation, however, tests performed with the spectrometer indicated a scoring higher than $50 \%$ in the value of light intensity, when in the presence of the lens. In the absence of refrigeration systems, the sample can reach temperatures of about $52{ }^{\circ} \mathrm{C}$, favoring the denaturing of DNA and proteins. In this way, the glass box gives off the generated heat efficiently, guaranteeing that the temperature of the sample is raised at the most $3{ }^{\circ} \mathrm{C}$.

The emission spectrum of the equipment studied, superimposed with the photosensitizer absorption used is shown in Figure 2.

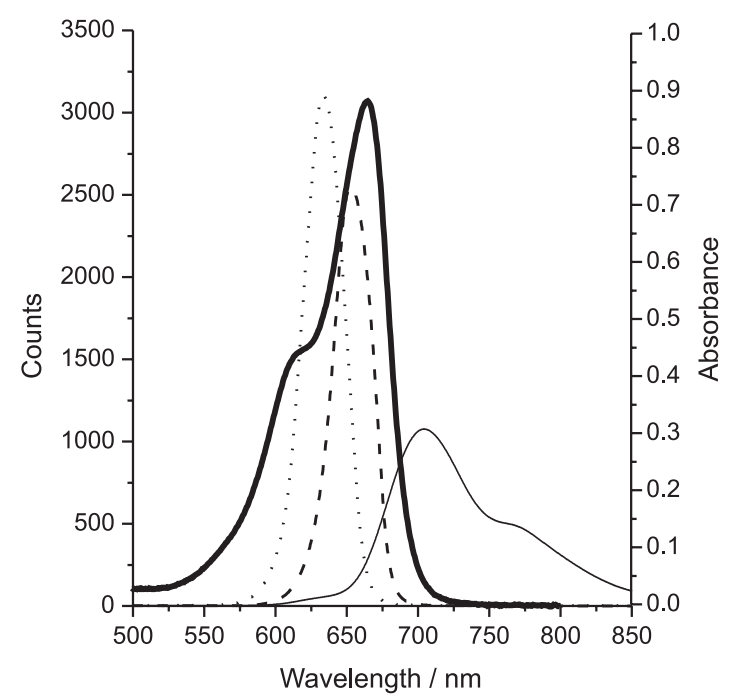

Figure 2. Absorption spectrum for methylene blue (-); emission spectrum of PHLS (-), LED600 (….) and AMS-II (----).

LED600 presents a wide emission area: $360 \mathrm{~cm}^{2}$, sufficient homogeneity (seen with spectrometer) and low heating. For this equipment we kept the distance of $11 \mathrm{~cm}$ for a better homogeneity/intensity relation, which was used in the microbiological experiments and in the degradation of DPBF. The systems based on LED arrays should present an ideal working distance seeing that, in a LED, the polymeric pack acts as a lens: a greater proximity means that the sample is very near to the focus, and, therefore, the irradiation is not homogeneous; the increase in the distance 
Table 1. Optical Power (P), Irradiation Area (A), Irradiance (Ir) and estimated excited fraction of photosensitizer (R), in the conditions used

\begin{tabular}{lccccc}
\hline Equipment & $\mathrm{P} / \mathrm{mW}$ & $\mathrm{A}^{\mathrm{a}} / \mathrm{cm}^{2}$ & $\mathrm{Ir} /\left(\mathrm{mW} \mathrm{cm}^{-2}\right)$ & $\left.\Phi /(\text { Einstein s})^{-1}\right)$ & $\mathrm{R}^{\mathrm{b}}$ \\
\hline PHLS & 2.90 & 132 & 1.80 & $1.7 \times 10^{-8}$ & 6.33 \\
LED600 & 20.11 & 360 & 12.46 & $1.6 \times 10^{-7}$ & 18.58 \\
AMS-II & 19.69 & 95 & 12.21 & $1.07 \times 10^{-7}$ & 31.36 \\
\hline
\end{tabular}

${ }^{a}$ Homogeneous irradiation area. Refers only to the possibility of irradiation of greater numbers of samples at the same time. Maximum variation in $\pm 5 \%$ of intensity. ${ }^{\text {b } C a l c u l a t e d ~ w i t h ~ r e s p e c t ~ t o ~ m e t h y l e n e ~ b l u e ~} 10^{-6} \mathrm{~mol} \mathrm{dm}^{-3}$ in sodium chloride $0.9 \%$.

tends to improve the distribution of the radiation, on the other hand great distances of the light source compromise the intensity of the light received.

AMS-II, although having intensity very close to LED600, has the peak of emission at $652 \mathrm{~nm}$, being still closer to the maximum absorption of the drug $(663 \mathrm{~nm})$. Emission of AMS-II is not only more appropriate for this drug, as it is also very homogeneous, as seen in additional tests with the spectrometer. The emission area of $95 \mathrm{~cm}^{2}$ (Table 1) could be increased by the simple addition of more LED in the array. This system presented irradiance values near $43.35 \mathrm{~mW} \mathrm{~cm}^{-2}$. The information on the irradiation area with homogeneous intensity, optical power, irradiance, and a fraction of excited molecules obtained from each equipment is summarized in Table 1.

The useful fraction of light that excites the fenotiazinic coloring is different for each equipment. It is possible to observe that the emission region of LED is sufficiently adjusted for the region of better drug electronic excitement, since PHLS presents low magnitude in the excitement of the photosensitizer $(R=6.33)$, basically in regard to the reduced photonic emission in the region of the band of absorption of methylene blue. The PHLS region emitted is sufficiently appropriate for other drugs, as for example, the class of phthalocyanines, since the absorption peak of the $\mathrm{Q}$ band of these drugs is located near the region between $675-700 \mathrm{~nm}^{35}$ These emissions are normally difficult to be obtained using conventional LED, because commercially available LED emission values above $650-660 \mathrm{~nm}$ are not usual.

Even though the LED600 and AMS-II are close, it is expected that AMS-II would have greater efficiency in generating reactive species due to its irradiation being capable of exciting a greater fraction of molecules of the photosensitizer $(\mathrm{R}=31.36)$ compared to the rest of the equipment. This phenomenon can be explained because of the emission of this equipment found in the band of greater light absorption by the photosensitizer.

\section{Confirmation of singlet oxygen presence}

Solutions with sodium azide $\left(\mathrm{NaN}_{3}\right)$ were used in order to give evidence of the participation of singlet oxygen in the process (Figure 3). Sodium azide is known as a strong singlet oxygen quencher $\left(10^{8} \mathrm{dm}^{3} \mathrm{~mol}^{-1} \mathrm{~s}^{-1}\right.$ in $\left.\mathrm{H}_{2} \mathrm{O}\right) .^{33,37,38}$ In all the equipments similar profiles of DPBF oxidation and suppression by azide were observed, Figure 3 shows the results observed with the LED600 equipment.
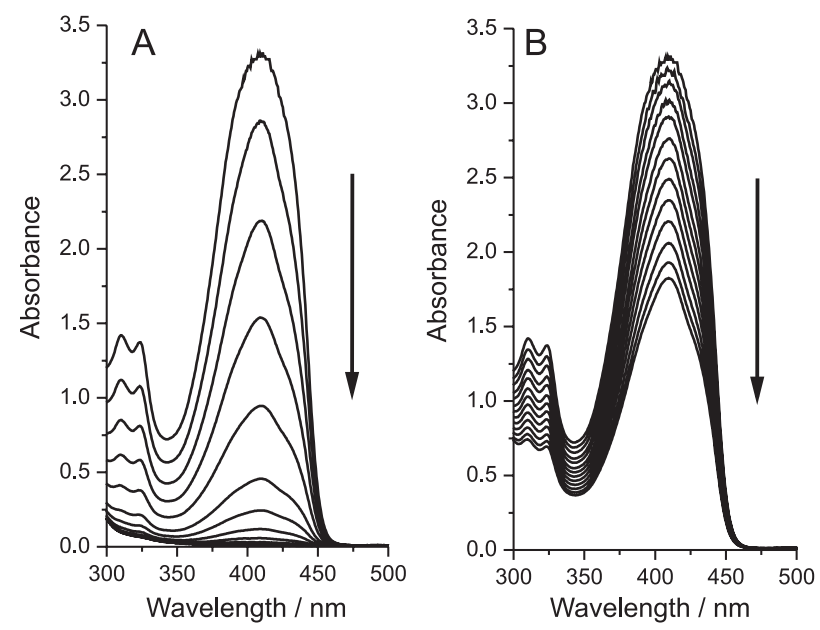

Figure 3. Photo-induced oxidizing of DPBF in LED600, in the absence of $\mathrm{NaN}_{3}(\mathrm{~A})$, and in the presence of $\mathrm{NaN}_{3}(\mathrm{~B})$. Each spectrum corresponds to $5 \mathrm{sec}$ of irradiation.

It is possible to observe in Figure 3B, that in the presence of $\mathrm{NaN}_{3}$, a reduction in the oxidation speed of DPBF occurs. The absorption peak in the DPBF region is found in the $429 \mathrm{~nm}$ region and shows the Figure that the mechanism of oxidation by participation of singlet oxygen is predominant.

\section{Kinetic comparison of photo oxidation of DPBF}

A kinetic study allows the quantification ion of to express the efficiency in the generation of ROS by emitted light of equipment built in the photo degradation of DPBF. Equation 2 expresses the degradation of the oxidable substract by the action of singlet oxygen. The concentration of singlet oxygen can be admitted as constant because the solutions were keeping contact with air and under constant agitation. Thus, it is possible to incorporate $\left[{ }^{1} \mathrm{O}_{2}\right]$ into the kinetic constant $\mathrm{k}$, resulting in a pseudo-first order constant, $\mathrm{k}$ '. In this way, the resultant kinetics is of pseudo-first order (equation 3 and 4). After the integration the equation obtained for the process is express in equation 5. 33,36 
$\mathrm{DPBF}+{ }^{\mathrm{I}} \mathrm{O}_{2} \longrightarrow \mathrm{DBB}$ and other products

$\mathrm{v}=\frac{\mathrm{d}[\mathrm{DPBF}]}{\mathrm{dt}}=-\mathrm{k}\left[{ }^{1} \mathrm{O}_{2}\right][\mathrm{DPBF}]$

$\frac{\mathrm{d}[\mathrm{DPBF}]}{\mathrm{dt}}=-\mathrm{k}^{\prime}[\mathrm{DPBF}]$

$\ln \left(\frac{[\mathrm{DPBF}]}{[\mathrm{DPBF}]_{0}}\right)=-\mathrm{k}^{\prime} \mathrm{t}$

A reduction in the concentration of DPBF in regard to time is shown in Figure 4, for all equipments.

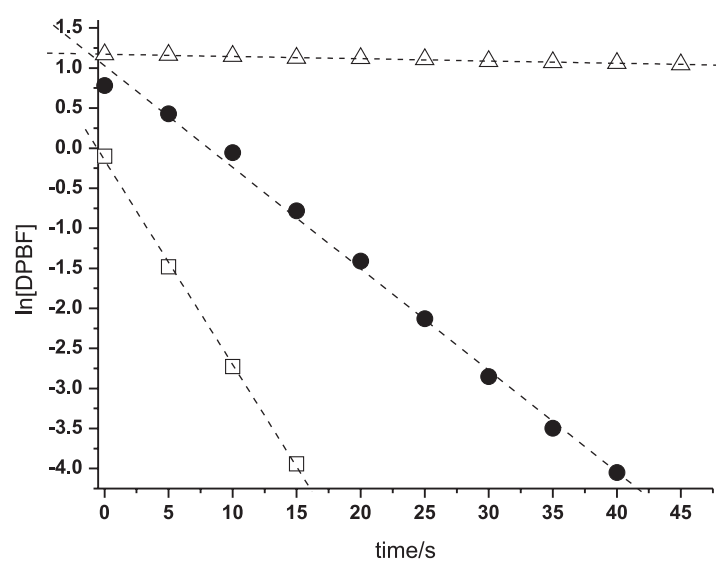

Figure 4. Kinetics of pseudo-first order corresponding to the degradation of DPBF induced by irradiation of various equipments developed. $(\triangle)$ PHLS; (๑) LED600; ( $\square$ ) AMS-II.

Each spectrum was obtained after $5 \mathrm{sec}$ of exposition to emitted light by the equipment. Thus, it is observed that for the AMS-II, only $20 \mathrm{sec}$ were sufficient for a reduction greater than $98 \%$ of intensity of the DPBF band.

These results suggest that AMS-II presented better performance. These tests are also in accordance with the values shown in Table 1. In these experimental conditions, it is still possible to say that AMS-II presents twice the efficiency of LED600 $\left(\mathrm{k}_{\text {AMS }}^{\prime}=0.25532 \mathrm{~s}^{-1} ; \mathrm{k}_{\text {LED }}^{\prime}=0.12668 \mathrm{~s}^{-1}\right)$. However, PHLS, in view of the small emission in the useful working band, presents an efficiency quite reduced when compared to LED-based equipments.

\section{Photodynamic inactivation}

Methylene blue, in the absence and in the presence of light, presents bactericide action in particular against gram-positive bacteria. These effects are described in the literature. ${ }^{39,40}$ The results of the bacterial inhibition by the presence and absence of light, are arranged in Figure 5. The samples were irradiated for $20 \mathrm{~min}$.

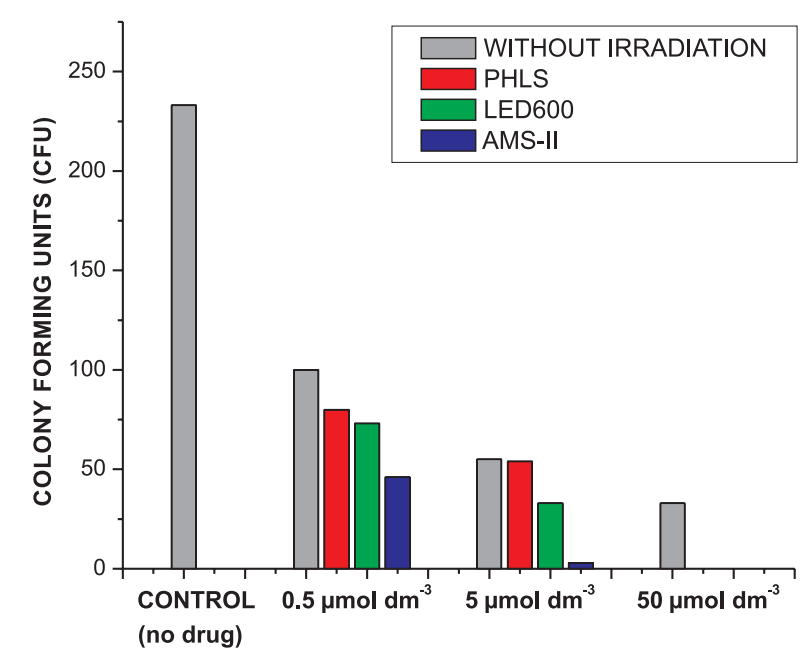

Figure 5. Bacteria count before and after the exposure of light, under three different concentrations of methylene blue: $5 \times 10^{-5}, 5 \times 10^{-6}$, $5 \times 10^{-7} \mathrm{~mol} \mathrm{dm}^{-3}$. Solutions in the same concentrations and non-irradiated were used as control.

The bacterial inhibition in the dark, for the more diluted solution $\left(5 \times 10^{-7} \mathrm{~mol} \mathrm{dm}^{-3}\right)$, presents a reduction, of approximately $50 \%$, in the number of colony forming units. In the equipment of greater efficiency, AMS-II, methylene blue under irradiation photo inactivated $75 \%$ of the bacteria reducing by $50 \%$ of the colony forming units compared with the dark control.

In all the other concentrations, the AMS-II equipment presented photo inactivation superior to $99 \%$. The other equipments, LED600 and HPLS also presented satisfactory performances of photo inactivation. At the concentration of $5 \times 10^{-5} \mathrm{~mol} \mathrm{dm}^{-3}$ and after light application, there was no colony formation. Therefore, all the equipments described operate satisfactorily against growth inhibition of Staphylococcus aureus in vitro. The obtained results in photodynamic inactivation agree proportionally to the results obtained with the DPBF oxidation and with the respective $\mathrm{R}$ values of each equipament.

\section{Conclusions}

All the equipments built proved to be capable of generating oxygen singlet, as was observed in the discoloration of the DPBF, in the suppression by $\mathrm{NaN}_{3}$ and photo inactivity of Staphylococcus aureus.

The study enables one to conclude that high power LED equipment proved to be able to excite a more significant fraction of molecules of the photo synthesizer, and consequently showed a more significant generation of oxygen singlet, as was observed more significantly by the magnitude of the kinetics of discoloration of DPBF, and bacterial inhibition. The reasons for this are relatively 
simple: the high powered LED used emits in wavelengths near to the peak methylene blue absorption aside from having high fluency. The system that uses a halogen bulb presents low photonic emissions, even though other optic filters may be used.

High powered LED are more effective photochemically aside from showing cost advantages and set up practicality.

\section{Acknowledgments}

The authors are indebted to Prof. Dr. Antonio Eduardo da Hora Machado for his valuable contribution to this study. To Laboratório de Fotoquímica and Laboratório de Fotoquímica de Lignocelulósicos from Universidade Federal de Uberlândia, for the concession of the infrastructure and materials. To CNPq, FAPEMIG and Nanobrax (www.nanobrax.com) for research support.

\section{References}

1. Gad, F.; Zahra, T.; Hasan; T.; Hamblin, M. R.; Antimicrob. Agents Chemother. 2004, 48, 2173.

2. Wainwright, M.; J. Antimicrob. Chemother. 1998, 42, 13.

3. Perussi, J. R.; Quim. Nova 2007, 30, 988.

4. Machado, A. E. H.; Quim. Nova 2000, 23, 237.

5. Dougherty, T. J.; Gomer, C. J.; Henderson, B.W.; Jori, G.; Kessel, D.; Korbelik, M.; Moan, J.; Peng, Q.; J. Natl. Cancer Inst. 1998, 90, 889.

6. Weishaupt, K. R.; Gomer, C. J.; Dougherty, T. J.; Cancer Res. 1976, 36, 2326.

7. Komerik, N.; Nakanishi, H.; MacRobert, A. J.; Henderson, B; Speight, P.; Wilson, M.; Antimicrob. Agents Chemother. 2003, 47, 932.

8. Wong, T-W.; Wang, Y-Y.; Sheu, H-M.; Chuang, Y-C; Antimicrob. Agents Chemother. 2005, 49, 895.

9. Qin, Y.; Luan, X.; Bi, L.; He, G.; Bai, X; Zhou, C.; Zhang, Z.; Lasers Med. Sci. 2008, 23, 49.

10. Alaya, F.; Grimaldi, E.; Perfetto, B.; Donnarumma, M.; De Filippis, A.; Donnarumma, G.; Tufano, M. A.; Photodermatol. Photoimmunol. Photomed. 2008, 24, 237

11. Donnelly, R. F.; McCarron, P. A.; Tunney, M.M.; Microbiol. Res. 2008, 163, 1.

12. Huang, Z.; Photodiagnosis Photodyn. Ther. 2008, 5, 285.

13. Alves, E.; Costa, L.; Carvalho, C. M.; Tomé, J. P.; Faustino, M. A.; Neves, M. G.; Tomé, A. C.; Cavaleiro, J. A.; Cunha, A.; Almeida, A.; BMC Microbiol. 2009, 9, 70.

14. Tirand, L.; Thomas, N.; Dodeller, M.; Dumas, D.; Frochot, C.; Maunit, B.; Guillemin, F.; Barberi-Heyob, M.; Drug Metab. Dispos. 2007, 35, 806.

15. Stukavec, J.; Duchac, V.; Horak, L.; Pouckova, P.; Photomed. Laser Surg. 2009, 27, 107.
16. Marotti, J.; Aranha, A. C.; Eduardo C. D.; Ribeiro, M. S.; Photomed. Laser Surg. 2009, 27, 357.

17. Almeida, J. M.; Theodoro, L. H.; Bonfante, S.; Luize, D. S.; Macarini, V. C.; Bosco, A. F.; Nagata, M. J. H.; Garcia, V. G.; Periodontia 2006, 16, 34.

18. Câmara, F. P.; Elias, C. A.; An. Bras. Dermatol. 1978, 4, 53.

19. Tardivo, J. P.; Petri, V.; Bonetti, T, I.; Oliveira, L. S.; Baptista, M. S.; Jornal Brasileiro de Laser 2007, 1, 28.

20. Tardivo, J. P.; Giglio, A. D.; Oliveira, C. S.; Gabrielli, D. S.; Junqueira, H. C.; Tada, D. B.; Severino, D.; Turchiello, R. F.; Baptista, M. S.; Photodiagnosis Photodynamic Ther. 2005, 2, 175.

21. Farmacopéia Brasileira, 2a. ed., Atheneu São Paulo, 1959, p. 119.

22. Krol, J.; Cahiers D'Anesthésiologie 1968, 17, 333.

23. Dahshan, A.; Donovan, G. K.; Pediatrics 2006, 117, e806.

24. Babilas, P.; Landthaler, M.; Szeimies, R-M.; Eur. J. Dermatol. 2006, 16, 340.

25. Demian, A. E.; Britto, J. R.; de Freitas, L. C.; Farias, V. J.; Coelho, E. A. A.; Vieira, J. B.; $12^{\text {th }}$ European Conference on Power Electronics and Applications, Aalborg, Denmark, 2007.

26. Phillips Lumileds Lighting Company, Datasheet DS45, March 2006.

27. Patrice, T. In Comprehensive Series in Photochemistry and Photobiology; Hader, D. P.; Jori, G., eds.; The Royal Society of Chemistry: Cambridge, 1994, ch. 7.

28. Ferreira, I.; Rahal, S. C.; Rocha, N. S.; Gouveia, A. H.; Corrêa, T. P.; Carvalho, Y. K.; Bagnato, V. S.; Veterinary Dermatology 2009, 20, 174.

29. Szeimies, R. M.; Matheson, R. T.; Davis, S. A.; Bhatia, A. C.; Frambach, Y.; Klövekorn, W.; Fesq, H.; Berking, C.; Reifenberg, J.; Thaçi, D.; Dermatol. Surg. 2009, 35, 586.

30. Barolet, D.; Semin. Cutan. Med. Surg. 2008, 27, 227.

31. Bonacin, J. A.; Engelmann, F. M.; Severino, D.; Toma, H. E.; Baptista, M. S.; J. Braz. Chem. Soc. 2009, 20, 31.

32. Kingbright Corporation, Datasheet WP7113PR51C/A, August 2007.

33. Bell, J. A.; MacGillivray, J. D.; J. Chem. Educ. 1974, 51, 677. 34. Rubinstein, E.; Int. J. Antimicrob. Agents 2008, 32, S18.

35. Rosenthal, I.; Photochem. Photobiol. 1991, 53, 859.

36. Young, R. H.; Brewer, D.; Keller, R. A.; J. Am. Chem. Soc. 1973, 95, 375.

37. Foote, C. S.; Org. Chem 1979, 40, 139.

38. Harbour, J. R.; Issler, S. L.; J. Am. Chem. Soc. 1982, 104, 903. 39. Li, W. Y.; Xu, J. G.; He, X. W.; Anal. Lett. 2000, 33, 2453.

40. Rohs, R.; Sklenar, H.; Indian J. Biochem. Biophys. 2001, 38, 1. 41. Zhao, G.-C.; Zhu, J.-J.; Zhang, J.-J.; Chen, H.-Y.; Anal. Chim. Acta 1999, 394, 337.

Received: June 6, 2009 Web Release Date: December 21, 2009 